\title{
UKRAINIAN PROSE OF THE 2OS OF THE TWENTIETH CENTURY: THE POETICS OF IMPRESSIONISM
}

\section{Zhurba S. S.}

\section{INTRODUCTION}

Ukrainian prose of the 20-30s of the twentieth century declared genre and style diversity, striking with an unusual combination of formal techniques, various techniques, synthesis of different types of arts. Developing under the influence of modernism, literature continues the trends proclaimed at the turn of the nineteenth and twentieth century. The impressionistic prose of this period declares the expansion of ideologicalthematic horizons, which causes the need to penetrate the inner world of the characters, to reveal the subtlest disturbances of the human soul.

Arising in painting, impressionism manifested itself in artistic texts. The phenomenon of Ukrainian impressionism is associated with the work of Kotsyubynskyi. It is testified in the research of Chernenko "Mykhailo Kotsyubynskyi - Impressionist", Kuznetsov "Impressionism in Ukrainian prose of the late XIX - early XX centuries", Ageeva "Ukrainian impressionistic prose". Continuing the tradition of the word's master, writers of the 1920s - Golovko, Dniprovskyi, Ivchenko, Hryhoriy Kosynka, Mykhailychenko, Pidmogilnyi, Turyanskyi, Khvylovyi and others multifaceted reflect on human and reality.

The prose is marked by the search for new forms and stylistic updates. The realities of life of Ukrainians are represented by themes: a person in a complex era of revolutionary events, spiritual possibilities of a lonely personality, leveling of personality under the pressure of Soviet reality, a collision of mind with instincts, etc. The true image of reality is expressed through romantic means, naturalistic scenes, associative images, fiction, satire, and grotesque. The reception of the psychology of a man and his inner world is explicated by impressionistic stylistics. Impressionist technique: fragmentation, bright colors, sunshine, the languages of bright brush strokes, dynamism are decisive in the literature of the post-revolutionary era.

Artistic searches for writers of different ideological and aesthetic trends of this era are reflected in the image of a man and the world. Within the limits of impressionism, neo-romanticism, expressionism, existentialism Ivchenko, Kosynka, Mykhailychenko, Panch, Pidmogilnyi, Khvylovyi, Yanovskyi reproduce the dynamics of internal changes of the individual in 
the period of complex political and social repercussions, accentuate the inner drama of a personality with an inner split and forked psyche. Feeling in love with life and optimistic belief in the future are combined with the loneliness and need of former active fighters for new ideals. In the 1920s, writers drew on material and ideas on the acute social conflicts of Ukrainian society. Artistic and philosophical understanding of reality and contradictory processes of this period allowed the artists to convey the subtle nuances of the inner world of a man, his split and ambiguity in complex political events, the destruction of moral and ethical priorities.

The generation of artists of the 1920s uses various shaping and stylistic techniques to convey the inner world of a man. The emphasis on reproducing moments of a person's life in a crisis period, "on the verge", allows writers to identify the subtlest disturbances of character's psychology, determined by the rethinking of a system of values and own existence. There ception of the poetics of Ukrainian impressionistic prose has been realized by scholars Ageeva, Bezhutrym, Kavun, Kuznetsov, Prygodiyi, Romanenko, Rudenko, Filatova, Yamchuk, andothers.

\section{The genre peculiarity of prose: intermedial discourse}

Ukrainian prose of the 1920s demonstrates a wide range of genre forms: short prose (short story, sketch, watercolor sketch, previous outline, and novelty), a story (socio, autobiographical, socio-historical, adventure, impressionistic, story-chronicle), a novel (experimental, intellectualphilosophical, urban, marine, song novel, novel in novelties). The authors search for new subjects and forms of expression, feeling the need to scale up the important issues of the era. In the process of artistic search, Ukrainian writers of the late 19th - early 20th centuries developed techniques and modified genre forms, which made the interpenetration of literature and art. The artistic expressiveness of related arts - music, painting, cinema, architecture, theater - allows writers to express genre and style settings. Different kinds of arts interact not only in terms of content, but also in terms of form and structure, and determine the structural features of the works.

In fiction, the genres of painting and music are used by analogy, representing the peculiarities of composition and verification of the corresponding work of art: a watercolor sketch ("On the Stone" by Kotsyubynskyi, poetry by Semenko), an etude ("The One (Viburnum trails)", "Spring Night" by Ivchenko), a symphony (Lyubchenko's "Vertep"), a sonata (Kulish's "Pathetic Sonata") and others. Features of impressionistic "poetics of impression" actualized the interaction of different types of arts: verbal, musical, cinema, and painting. 
Intense development of short genres occurs in the early 20 s, during this period they are replaced by a story and a novel. Short epic forms (short story, sketch, and novella) are presented by the collections of "Novelties" by Mykhailychenko, "Blue Sketches" by Khvylovyi, "Militarypilot", "The problem of bread" by Pidmogylnyi, "The girl on the road", "Red Scarf" by Golovka "Mammoth tusks", "Blood of the Earth" by Yanovskyi and others. The most common form is the novella: psychological (Khvylovyi, Pidmogylnyi, Antonenko-Davidovich), impressionistic (Kosynka, Golovko), philosophical (Pidmogylnyi, Lyubchenko, Shkurupyi). The dramatic depiction of the events of the Civil War, severe post-war reality, famine, and post-war devastation can be traced in the works of artists. In stories and novelties, the authors recreate the truth of life, human fate and focus on the psyche of the hero.The works of this period are characterized by the expressiveness of plot and compositional elements, the symbolism of images, play with words, and telling artistic detail. Psychological prose reveals the image of the intellectual against the background of the revolution and its adaptation to a new life ("History of Mrs. Yvga" by Pidmogylnyi, "Blue leaf fall" by Khvylovyi). As a representative of neo-romanticism, Yanovskyi addresses the theme of adventure, romantic stories, intriguing the reader with enigmas and unexpected plot twists ("Roman Ma", "Blood of the Earth"). Psychology with story lyricism and impressionistic technique is combined in the novels by Kosinka and Lyubchenko. Focusing on national traditions, the authors move to the European level in modifications of the genre.

A novella is characterized by the fragmentation of the image of reality, the montage of paintings, the relief of the images presented through the artistic detail and symbolism. Creating a picture through a sketch drawing, an eloquent detail allows the author to express the artistic world of the work.Theemotionalandlyricaltoneofthenovellaisexpressedbythecolor, sound, dynamics of events. These are the novels "I (Romance)", "The cat in the boots" by Khvylovyi, "For the land", "In the rye", "Politics", "The dog" by Kosynka, "To the earth", "From the field days" by Ivchenko, "Via dolorosa" by Lyubchenko. The search for new expressive forms predetermined the compositional structure of the work, which is close to other types of art painting, music, architecture, theater, and cinema.

The combination of expressive properties of verbal-figurative, visual, auditory kinds of creativity promotes the interaction and interconnectivity of syntactic, lexical-semantic trails and allows the artist to create his author's picture of the world.Genre varieties of novelty testify to the synthetics of prose: watercolors, sketches, symphonies, sonatas, brush strokes, designs. Critics point out that the rhythm-melodics of impressionistic works 
demonstrate a connection with music (for lyrics) and painting (for prose). Such borrowing, according to Nalyvayka, is a characteristic feature, of "artistic expressive means, which are necessary for the realization of tasks common to all the art of impressionism: early impressionistic prose borrowed from painting and lyrical poetry from music". Impressionist stylistics conveys auditory and visual impressions, captures colors and smells, declaring painting and music principles for the creation of a work.

Musical images become a tool for the rhythmic dynamism of prose, the revelation of the psychology of characters. The fixation of the life moment, the transfer of the hero's mood, his experience is transferred into a sketch. Reflections of the lyrical hero of Ivchenko's work "The One" are in harmony with the state of nature, the August landscape. The writer uses metaphor, resorts to meditation, which emphasizes the hero's connection with nature. The absence of the plot is offset by reflection and the transmission of the character's state of mind through association: a road covered with berries of guelder rose, which are mercilessly trodden by a loved one, leaving bloody footprints. The use of color-sound images, the transparency of the rhythm, the poetization of nature, the reflection of the emotional state determines the stylistic dominant of the work -impressionism.

The combination of heterogeneous elements, fragmentation, and dynamism characterize the genre of arabesque in literature. The bizarre patterns, the repetition of fragments, the intricate interweaving of the plots create a sophisticated picture like the impressionist paintings, and it is perceived only from a distance. Khvylovyi's novella "Arabesque" testifies to moving away from the usual principles and compositional techniques of text creation. The writer successfully combines and contrasts various aspects, stringing imaginary and real episodes. The picture of that time reality was transmitted through the prism of the author's perception. The reader understands the whole picture of reality through the consciousness of the artist: "Everything here on earth is lost in the chaos of the planetary movement and only barely shines in the consciousness", "both heroes and events and adventures that did not exist at all seem to go and they will never,

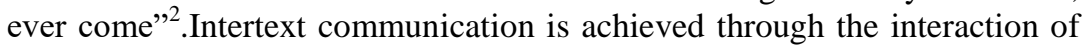
ornamented video sequences and author's instruction.

The genre of orchestral music has moved into the literature, enriching it with new imagery. The melodious combination of tones, harmony of sound,

\footnotetext{
${ }^{1}$ Наливайко Д. Теорія літератури й компаративістика. Київ : Вид. дім “КиєвоМогилянська академія", 2006. С. 29.

${ }^{2}$ Хвильовий М. Твори : у 2 т. Київ : Дніпро, 1990. Т. 1: Поезія, оповідання, новели, повісті. С. 174.
} 
and words are determined in the genre of the symphony. The impressionistic moment of the aesthetic perception of reality, which is dominant in impressionism, corresponds to the nature of the melody. The development of a special method of musical thinking was realized in the poetry of Tychyna, Sosyura, Antonych, Rylskyi, and others. The prose used the originality of phrasing, orchestration, and text structuring. Examples include the works "Beyond the limits of pain" by Turyanskyi and Lyubchenko's "Vertep". The structure of the symphony as a prose genre is determined by the division into several independent parts, the symmetry of material placement, periodicity, and rhythm of construction, the balance of proportions, circular framing, and the principle of contrasting oppositions. The music genre has enriched literature both formally and substantively. The organization of the dynamics of the "lyrical story in novellas" (Pizniuk) "Vertep" by Lyubchenkois referred through the rhythm melodic of each part of the work, "laconic polyphonic" and expressed in the titles: lyric solo, melodrama, mystery, dance, and puppet performance. Also, each of the sections of the novel has its mood and musical tone. Gamorak and Sherekh pointed to the construction of Lyubchenko's works according the laws of musical art. Musical arabesque in the story is expressed through an ornamental melodic pattern. Sound dominance is transmitted by movement, expressed in color, and a blend of diverse tones and half tones, that create a kaleidoscope of shades and sounds. Musical principles of construction of the work testify to the "polyphonic sound of the text at different levels (structural, lexico-semantic, stylistic), the rhythm melodic of the text, the use of a wide range of musical terms, the combination of words and sound images"3. The symphony genre defines the inter-media nature of the work, a new type of artistic thinking and genre.

The desire for unity of content and form deepened in the genre of a sonata, which also entered the literature from music. Depth of content, intense contrast of images, new means of expressiveness (symbols, metaphors) in Ukrainian literature are more fully realized in the drama "Pathetic sonata" by Kulish. The play has epic features because the author transformed the prose into dramatic. The dramatic plot, repetition of certain elements, the different tone of parts (chords grave, allegro molto e con brio), author's remarks indicate the specificity of the genre. The famous music of L. van Beethoven becomes the background for the unfolding of the events in the play and the internal generator of the character's state. Interaction of

${ }^{3}$ Журба С. “Вертеп” Аркадія Любченка: музичний контекст. Філологічні студї: Науковий вісник Криворізького державного педагогічного університету : зб. наук. праць. Кривий Ріг: НПП Астерікс, 2016. Вип. 15. С. 162. 
intertextual discourses in the work of Kulishis revealed by mythological, biblical, ethno cultural, and musical proto-texts.

The direct live impression of reality in the "watercolor" genre is expressed in plastic-visual images. The works of Kotsyubinskyi serve as an example in the literature of impressionism. A short fragmentary story, a landscape sketch presented in the works "On the stone", "Mountain watercolors" by Kotsyubynskyi, and the poetry of Semenko. Varieties of watercolors are sketches, patterns, and etudes. Watercolor implies a peculiar technique of performance: the colorfulness of the colors, the holistic perception of the depicted picture (human, landscape, mood atmosphere), and the originality of the composition. Associative, knitting patterns are achieved by the multidimensional shades of color. As noted by the literary scholar Focka, "one of the most common means of suggestion of picturesque images at the artistic and verbal level is the nomination of color, which automatically paints the vision that appears in the imagination of the reader" 4 .

The syncretism of sensations, colors and sounds in impressionistic artwork generates particular poetics. The color and figurative drawing of the word gives the works of meaningful content, melody, and picturesque expressiveness. Symbolism, associative relationships enhance the perception of reality. The use of expressive means of different kinds of arts indicates lyricism, the plasticity of images, emotionality, intermedia of prose. The emphasis on the feeling and perception in the poetics of Impressionism brings the world of musical, visual, and verbal art closer together, creating an eclectic impressionistic fusion.

The Ukrainian story of the 1920s is a multifaceted work, a characteristic feature of which is the depiction of life in various manifestations through of deepening into the subconscious of the individual, and the use of psychological analysis. The search for such a structure of work that would impress the originality of the subject matter, style, and plot in the 1920s led to the enrichment of literary achievements in the genre of the story. In the post-revolution period, the impressionistic genre of story acquired new features and became an acutely problematic one, thereby increasing its ability to respond quickly to the phenomena of life. The 1920s were a time of bright discoveries in the story genre: symbolic ("Blue novel" by Mikhailchenko), impressionistic ("Spring noises", "Burning steppes" by Ivchenko, "I can", "Red novel" by Golovko, "The sanatorium zone" by Khvylovyi), expressionistic ("Beyond the boundaries of pain" by Turyanskyi), a detective (Smolich), adventure (Dosvitnyi, Yanovskyi), satirical ("Ivan Ivanovich" by Khvylovyi).

4 Фока М. Функціонування кольору в поетичних творах Павла Тичини. Українська література в загальноосвітній школі. 2009. № 6. С. 2. 
The impressionistic story of that time became a kind of a "polygon" for testing new compositional searches for Ukrainian prose. According to critic Biletskyi, it was "a lyrical story-rhapsody with introductions and finals, with the transition of rhythm to verse, with care for sound instrumentation, with the musicality of the composition"5 occupied a prominent position among the artistic experiments of the time. Contemporary literary scholars support this claim, noting that in this genre "the essence of the impressionistic vision - the inconsistency of the human "lifestyle" (dreams, hopes, wishes) of reality, and the principle of a "pluralistic universe", which naturally determines the art of fragmentation, is directly declared"6.

The peculiarity of the impressionistic story is the versatility of genre architectonics. This type of story is characterized by emotionality, expressiveness of the storytelling. The plot, as an integral structure, does not play an important role, and it is almost absent, because the main compositional core is the ideological and emotional mood of the narrator. The role of the author is minimized and superimposed on the word of the narrator, so the author's assessment is almost absent he acts as a third-party observer, and does not intervene, evaluate and comment on events and phenomena. The correlation of lyrical and epic beginnings, the instruction on the expression of subjective experience in the form of an internal monologue, expressiveness, and rhythm characterizes the genre of the poem in prose. The reproduction of the semantic context of the "Blue novel" by Mykhailychenko, "Beyond the pain" by Turyanskyi, the emotional mood of the works allowed the critics to define the definition as "a poem in prose". The lyrical subjective beginning, the refrain, the rhyming of the passages pointed to the connection with poetry. The magnitude of the image, the philosophical comprehension of being human in a "boundary" situation determined the epic nature of the works.

A new way of the art thinking in the early twentieth century encouraged the search for new artistic forms. Ukrainian literature of the 1920s, with its focus on internal reflections, human existence in times of social change, revolution, and post-revolutionary times, was national in content. Synthesis of genre varieties, syncretism of the arts predetermined the narrative structure of prose, pointed to the development and modification of the novella, story, novel.

${ }^{5}$ Білецький О. Зібрання творів: у 5 т. Київ: Наукова думка, 1966. Т. 3 : Українська радянська література. Теорія літератури. С. 36.

${ }^{6}$ Жанр і стиль літературного імпресіонізму України та США / укл. С.М. Пригодій. Київ : КДЛУ, 1996. С. 14. 


\section{An outline of prose texts}

Impressionism was manifested not only in the technique of writing, the form of meaningful methods of transmission of impressions but also in the transmission of the inner world of the characters, their subtle actions. The reflection of the movement of life, its fleeting and unique moment becomes the basis of the impressionistic technique. Mastery in the reproduction of the impulse of thought, the association of a nervous hero, who is in a state of mental stress, is achieved due to the so-called "chopped phrase".

In impressionist works, where events are transmitted through the worldview of the hero or narrator, there is a noticeable tendency to deep psychological characteristics, forms of "flow of consciousness", not proper direct speech or internal dialogue with himself. By choosing the form of the inner monologue, the writer-impressionist achieves that his hero (he often acts as a narrator) points to his dichotomy. Such are the protagonists in the works of Khvylovyi "I (Romance)", "Editor Kark", "Sanatorium zone", and Golovka "Red novel". The impressionist style of writing requires the activation of the inner thinking of the hero, which is described in the form of an inner monologue. The line between the narrator's speech and the actual direct language of the characters is almost completely blurred because the story is often told like first-person narration. The author's word is superimposed on the hero's word in the impressionistic story. The author cannot remain a passive observer, refrain from evaluations, he is closely within the framework of impartial imagery. In the works of Golovko, Ivchenko, Khvylovyi, Panch we observe a tangible introduction of the author's assessments of the depicted text, and the author's philosophical generalizations in the language of the characters. "The artist-impressionist sees his task only in fixing everything he feels, believing that the intensity of each, even the smallest, phenomenon recorded by him makes it possible to approach the meaning of the whole universe, a part of which was in his field of vision"7. Khvylovyi's "Sanatorium zone", Mykhailychenko's "Blue novel", Golovko's "Red novel" resort to a multi-vector narration (the story is told by both a heterodiegetic and homodiegetic narrator). The figure of the narrator is considered to be a distinctive feature of the story as an epic genre. This function is performed by a homodiegetic narrator in Golovko's "Red novel" and Ivchenko's "The red bell". In Kosynka's "Harmony" it belongs to a heterodiegetic narrator, an outside observer who often remains anonymous.

The basis of the artistic image of reality is subjectivity, confession, emotional openness. The lyricism is one of the main features of the

\footnotetext{
${ }^{7}$ Агеєва В. Українська імпресіоністична проза. Київ, 1994. С. 37.
} 
impressionist story. The thoughts of the hero-narrator of Ivchenko's story "The Earth is ringing" are full of confession, due to the internal conflict of the individual. The lyrical hero's self-analysis unfolds in the form of a stream of consciousness, reflections on his destiny, and the destiny of the world: "Mountains push on mountains, the big crack of the earth is audible from afar. I know: tomorrow a new beast will come from a stone cage and will bite a quiet man of the earth with iron ticks ...”8. Philosophical reflections and experiences of Semenovich ("The Earth is ringing" by Ivchenko) clarify the difficult situation of the day: "Evil, rage, and perseverance are, in my opinion, a force of one order. To defeat them means to stop the world, to put it at zero. Zero is the basis of the world. Two forces compete around it - positive and negative, and from that the streams of life are born. Zero is a wise calm, tense, and equal concentration and deep understanding of the world created by the former sages. But this is not what keeps the world going. The world is constantly swaying between plus and minus, and zero is just one moment of synthesis, one small point at which the paths of the world intersect by chance"9. The lyricism in the works of Ivchenko gradually became more dramatic, revealing the contradictions between the natural vocation of man and the possibilities of its actual realization.

The story in the works of Kosynka is mostly told by a heterodiegetic narrator, but he acts as an outside observer of events, does not interfere, and does not condemn, pointing out that everyone has truth. The hero of the works "In rye", "Shot", "Politics", "Dog" by Kosynka finds himself at the crossroads of political and social confrontation, his choice in the chaos of creating a new world. The author often singles out one important episode from the life of the character and unfolds it, penetrating the inner world. The real events in the short story "Conspiracies" are only a framework through which the writer recreates the inner state of Peter Rudyk. The rich peasant does not want to give the good he gained to the commune, so he takes a step that would save him: he wants to marry his daughter to a poor but hardworking boy. The story in the work is told by a heterodiegetic narrator, but we observe the events through the eyes of Peter Rudyk. The author carefully examines the mental state of the hero, his experiences, thoughts, and actions. The writer shows the man of the land, reveals the psychology of the peasant: whether a wealthy farmer or a landless poor man. Peter's mental confusion is also revealed by artistic details: a dream, the image of the wind, and

\footnotetext{
${ }^{8}$ Івченко М. Робітні сили : новели, оповідання, повісті, роман. Київ : Дніпро,

${ }^{9}$ Ibid., c. 554 .
} 1990. C. 425. 
horses. The individual inner "I" of the character is revealed through improper direct speech, inner monologue, "flow of consciousness", and artistic details.

Fragmentary composition, laconic plot, deep retrospectives, and landscape details are drawn through a chain of associations; inversion, personification, refrains - characteristic features of the poetics of Golovko's novels. At the center of the artistic world of the story, "Red novel" are two antagonistic psychologies - a revolutionary-collectivist and a poor peasant; the role of social landmarks is growing both in the interpretation of the psychology of the characters and in the depiction of the place and time of events. We see the use of the color symbol as the external equivalent of the internal state of the hero of Mykhailychenko's "Blue novel" and Golovko's "Red novel". Blue in Mykhailychenko's story is the external equivalent of the soul, and a sign of life - death -Immortality, corresponds to the world tradition of its comprehension. The symbolism of the "Red novel" is based on the realities of revolutionary events and the "social equivalent". The red color is a symbol of the revolutionary era and an analog of the inner world of the communards.

Color semantics is one of the compositional elements of impressionist work. The combination of shades, tones, halftones, and relationship with the state of the hero is a formative factor in the organization of artistic material. Writers-impressionists sought such associations of expression that would artistically logically and vitally convey human behavior and condition, paying attention to the deepening of the psychological capacity of the image and enriching the artistic structure of the stories. The colorfulness of painting in the impressionist story is achieved through the capacity of the phrase, and this allows to contain in short phrases that in the works of realists was detailed and divided (separated): description of the environment and mental state of the hero, action, and landscape: "An arch looked east. There was a commanding height. He remembered Maya, and now he wanted to hear her sonorous voice, her soft ugly laugh. And when he remembered that she was not at all now, that he might never see her as she was there at the beginning of the summer, it seemed to him that he had lost something impossibly precious. His best moments in the sanatorium zone were connected with this command height. And this wild raspberry, which now looked deserted in the middle of a silent field, and these poplars, and this transparent dove - all these are witnesses of his bright hopes, which occasionally appeared in him" ${ }^{10}$.Visual and sound images express the mood, feelings, inner state of

${ }^{10}$ Хвильовий М. Твори : у 2 т. Київ : Дніпро, 1990. Т. 1 : Поезія, оповідання, новели, повісті. С. 465. 
the hero. The author captures the feature of the character in the fleeting external and internal states. Showing the psycho-spiritual worldview of the hero at a certain moment, and the transfer of a momentary moment is the basis of the poetics of the impressionist story. The main type of hero is the image of a lonely, redundant, doomed man corresponded to the social structure of the environment, reflected the shift in social consciousness.

Capturing every moment of human life and society, impressionism dominates the turning points of history, conveying the initial impressions, feelings, moods of writers and their characters, which are embedded in the subconscious and have only just come to the surface. As a result, the concept of man changes in impressionist work.In the 1920s, such a man was a spiritually rich and spiritually devastated person (spiritual fullness and poverty constantly compete with each other). The spiritual dimension of man appears in the extreme form - understanding the meaning of life, the hero's solution to the ultimate issues of life, the transformation of his mental and inner spiritual world. Psychologism, as one of the methods of revealing the character of the hero in the impressionist work, determines the motive of the character's behavior at the turning points of his life, reproducing the dialectic of feelings. To reveal the inner world of the individual writers use internal monologues, "stream of consciousness", and indirect language. The lyrical tone testifies to the strengthening of the psychological saturation of the inner speech, the subjective reproduction of the human soul, the image of the human soul in a situation of crisis, which is characteristic of the impressionist prose of the 1920s.

\section{Time-space continuum of impressionist prose}

The time-space organization of impressionist prose is based on the principle of the trinity (place, time, and action), which fixes the fluidity of the moment of existence and is universalized at the same time. The originality of an impressionist work is revealed at the level of its design, thematic dominance, artistic perspective, chronotope, subject/object relations, conflict, and plot unity. Time-space isolation, focusing on one moment to obtain emotional content is a characteristic of impressionist prose. The impressionist chronotope is declared to be "plotless", the absence of a series of events, the shift of coordinates. The basis for the construction of works is not aesthetics or the development of events, not the plot, but the organization of lyrical components - emotions and impressions.

Analyzing the prose of Kotsyubynskyi, literary critic Kuznetsov notes that the writer's short stories "are not built on a basis of plot, but on the structure of experience"11. Defining the structure of Kotsyubynskyi's short

${ }^{11}$ Кузнецов Ю. Імпресіонізм в українській прозі кінця ХІХ - поч. ХХ ст. Проблеми естетики і поетики. Київ : Зодіак - ЕКО, 1995. С. 209. 
stories, the critic writes: "The circular construction is characteristic of the writer's short stories with a tangible epic beginning, in which the plot-event plan is to some extent expressed. For short stories with a predominant lyrical beginning are characterized by a mosaic combination of paintings" ${ }^{12}$. The main features of the mosaic construction are enhanced lyricism, the predominance of poetry over prose, associatively, and fragmentary paintings.

The events in Turyanskyi's story "Beyond pain" unfold within one day. The genre originality of the work (chronicle of near-death delusions) forced the writer to focus on one important moment in the life of the characters - the last day of the life of prisoners of the Austrian army. The area is concretized and clearly defined by geographical coordinates - the mountains of Albania, which indicates the historical authenticity. In the work we can distinguish several time planes that interact with each other. Firstly, it is a historical time, a reflection in human consciousness of the events of the First World War. Secondly, there is a biographical time in the work - a period, which relates to the image of the life of a particular person. The personal chronotope of each of the characters - Oglyadovskyi, Dobrovskyi, Pshiluskyi, Boyan, Nikolich, Sabo, Stranzinger - becomes especially relevant. The story of each of them unfolds in fragments, through memories, delusions, visions. Personal timespace is intertwined with the time of history and is conditioned by the author's composition of the art world. The space-time continuum reveals the inner world of the characters and correlates with the real image of the war. The chronotope of the road plays an important plot-compositional role connected with the stages of the characters' life path.

The circular construction of the impressionist work is caused by the epicness of the narrative, relative to the temporal sequence of the paintings depicted. The plot in such a work moves consistently, but the chronotopeis interrupted by memories, lyrical reflections of the hero, philosophical generalizations, landscape sketches, and diary entries. This type of structure is typical of most impressionist novels of the 1920s. The artistic structure of the works of Golovko "I can", Ivchenko "Watered days", Panch "Blue echelons" is determined not by the real subject world, but the mood, associations of heroes. The basis of the work is still emotional, focused on psychology, artistic structure in which both color and landscape are subject to the transfer of feelings of the heroes ${ }^{13}$.

${ }^{12}$ Кузнецов Ю. Імпресіонізм в українській прозі кінця ХІХ - поч. ХХ ст. Проблеми естетики і поетики. Київ : Зодіак - ЕКО, 1995. С. 210.

${ }^{13}$ Ibid. 
The event plot in impressionist prose turns into an inner one, determined by the collision of inner experiences. According to Ageeva, "the time of the impressionist short story is an episode of escape from society, from the epoch, from the usual circle of public and domestic responsibilities, temporary rupture of almost all external relations" $" 14$.A typical for Ukrainian literature of the early twentieth-century "intermezzo" chronotope is observed in the impressionist novel: "Intermezzo", "On the road" by Kotsyubynskyi, "In his native home", "To the land (Autumn lyrics)" by Ivchenko, "In rye" by Kosynka, Khvylovy's "Poodle", etc.

The change in space-time coordinates is a consequence of the fact that the time of the impressionist work is a moment specially separated from the flow of history. In contrast to a novella or narration, the story more specifically and fully depicts a segment of history and human life. For the most part, the events that formed the basis of the work are close to the writers. In this regard, Roman In garden pointed to two areas that are a manifestation of the phenomena of time perspective. They are represented and manifested in various phenomena of the chronotope, concerning individual phases or parts of the whole work (at all its levels). The critic noted that the work, as we know, can be written in the "present tense" or of various forms of "past tense". Sometimes the "future tense" is also used. Of course, for example, the terms "past tense" and "present tense" are used in stories ${ }^{15}$. The time of the impressionist story does not stay the same; it loses its patriarchal rigidity. Kaleidoscope, the ephemerality of events, and spatial coordinates is similar to a cinematic image. However, conveying the current state of the hero, correlating it with the past, the author dramatizes the events, yet the pictures of the future - bright, cheerful.

In the works of Khvylovyi, the pictures of the artistic image of reality consist of dynamic tension, rupture, and discreteness of time. Khvylovyi's story "Sanatorium zone" is limited to a few months. The event space is narrowed to the sanatorium and its surroundings. We learn about the past of the an arch and other characters through memories, short stories and dialogues between patients. The author focuses on the inner experiences of the an arch. The life drama of other residents of the sanatorium is intertwined with the space-time of the hero: the young poet Hloni, the nurse Katri, the KGB officer Maya. They all experience a similar drama: they feel their uselessness, "redundancy" in a new time for them.

${ }_{15}^{14}$ Агеєва В. Українська імпресіоністична проза. Київ, 1994. С. 108.

${ }^{15}$ Інгарден Р. Про пізнання літературного твору. Слово. Знак. Дискурс. Антологія світової літературно-критичної думки XX ст. / за ред. М. Зубрицької. Львів : Літопис, 1996. С. 158. 
Choosing a short section of the image - from one day to one month, the authors interrupt the present moment in the stories with a touch of past and future: memories, visions, thoughts, and dreams, insert short stories. If in Golovko'sstories the time of the art work and the time of the author are close. In Mykhailychenko's work the time perspective has no specific definition, because it is interrupted by historical reminiscences and goes beyond a certain historical segment. The chronotope of Mykhailychenko's "Blue novel" is conditional: the events take place either in Egypt during the colonial dependence on Great Britain or in Ukraine during the Civil War. The temporal reference is marked by a revolutionary reality and appropriate vocabulary.The non-linear plot, the inverse, inverted order of the parts of the work (the first chapter is called "Introduction", the work ends with "Dedication"), the mosaic structure, the fragmentary nature of the story indicate the impressionistic style.The time-space of Ivchenko's works is "condensed", reproduces one, often decisive, the moment of life. The author uses the technique of retrospection (return) in the story "Shadows are incorruptible". This organization of the chronotopic structure allows us to reconstruct the past through the memories of Stas. The author, recording the passage of time, reproduces the emotional experiences of the characters so that the present becomes clear only in the context of the past.

The chronotope of the Ukrainian impressionist story has its peculiarities. Subjective-sensual space-time does not abandon reality, sometimes with autobiographical inclusions, and also provides a microspace filled with mental-subjective time, in particular in the stories of Ivchenko "In the solar circle", Irchan "Carpathian night", Kosynka "Harmony", Panch "Without a trump card", "Blue echelons", Turyanskyi "Beyond pain". Along with the search for new form-content components in the narrative genre, we can see that "the plot in its old concept is disgusting. People, their thoughts and feelings - under the sign of revolutionary flood cannot be portrayed as their old storytellers wrote"16. Biletskyi and Mezhenko pointed out the absence of a plot in Ivchenko's works. Critics of Pidmohylnyi's novel "Ostap Shaptal" and Mykhailychenko's "Blue novel" expressed similar opinions. Biletsky, almost the only literary critic in the 1920s, wrote that Punch's novel "Without a trump" was "made with frequent changes of" frames ", speaking the language of cinema"17, and denied the realistic manner of the artist, which has long been attributed by critics early stories by Panch.

${ }^{16}$ Білецький О. В шуканнях нової повістярської форми. Шляхи мистецттва. 1923. № 5. С. 61.

${ }^{17}$ Білецький О. Петро Панч. Білецьький О. Зібранняпращчь : у 5 т. Київ : Наукова думка, 1966. Т. 3. Українська радянська література. Теорія літератури. С. 113. 
"Impressionist arabesque is the most noticeable in the narrative genre"18, because it is such a form that allows for reflection of the narrator and the characters, more fully reflects the action and state of the characters. The leitmotif construction, which underlies the construction of the plot, is one of the leading in the works of the lyrical type of organization of artistic material. The plot in the stories moves not due to the event but through the development of moods and experiences of the protagonist. The plot is one of the formative factors of the work of art. In the stories of the late 20s, along with the impressionistic storytelling, there was a tendency to plot, chronological sequence, epicness, caused by a certain departure from lyricism (poetry in prose).

\section{CONCLUSIONS}

In Ukrainian literature, impressionism was formed both under the influence of European artistic trends and as a result of the national development of art. The impressionists sought to evoke in the reader impressions, feelings that arose as a result of understanding the fate of man and Ukraine in an era of revolutionary changes. The closeness of the work of art to music (sonata, symphony, arabesque) and painting (sketch, watercolor, image) indicates the intermediality of literature. New principles of construction of the work testify to the polyphonic sound at different levels of text organization, the combination of words and sound images, the lyrical beginning in the epic work. Musical orchestration synthesizes and frames the mood of the artistic text, determines the originality of the structure, and emphasizes the "inner sound" of the word.

The main focus in the impressionist prose of the 1920s is focused on the expression of feelings, experiences, and emotions of the protagonist or narrator in a difficult era of political and social changes. In the artistic picture of the world the way of thinking of characters, their manner of conversation, merging of a word of the author with a word of the hero is important. Lyrical impregnations, which are in a sense a unifying element, give the works an expressive, emotional sound. Depicting the complex inner drama of the individual, revealing the state of mind of the hero, impressionists-writers tried to uncover the unattainable secrets of the human soul. Showing the hero alone, with a split, bifurcated psyche, a fracture in his soul caused by the corresponding changes in the world is reproduced by using psychological analysis: internal monologue, indirect speech, "flow of consciousness". The specificity of temporal and spatial coordinates in the impressionist work is marked by discreteness, discontinuity, density,

\footnotetext{
${ }^{18}$ Агеєва В. Українська імпресіоністична проза. Київ, 1994. С. 123.
} 
fragmentary image. The writers abandoned the depiction of the chronological sequence of the characters' lives, focusing on one extremely important point. There is a tendency to the individual-situational perception of time and space by the characters.

To convey the psychological state of the characters Mykhailychenko, Ivchenko, Kosynka, Turyanskyi, Khvylovyi use memories, visions, delusions, and imagination. "The rupture of the plot" in Ukrainian impressionist prose is associated with the reflection of the torn consciousness, the psychology of the man of the twentieth century, which faces a series of burdensome, unresolved problems.

\section{SUMMARY}

The article considers the poetics of Ukrainian prose's impressionism of the 1920s. The subject of research was the features of impressionist technique: narrative strategy, lyricism, type of hero, chronotope, the role of artistic detail. It is proved that the work of writers demonstrates a special worldview, which is expressed in in-depth psychologism, skillful reproduction of the subjective picture of the world, the peculiarities of spacetime, and the synthesis of different arts.

\section{REFERENCES}

1. Агеєва В. Українська імпресіоністична проза. Київ, 1994. 160 с.

2. Білецький О. В шуканнях нової повістярської форми. Шляхи мистеитва. 1923. № 5. С. 59-63.

3. Білецький О. Зібрання праць : у 5 т. Київ : Наукова думка, 1966. Т. 3. Українська радянська література. Теорія літератури. 607 с.

4. Івченко М. Робітні сили: новели, оповідання, повісті, роман. Київ : Дніпро, 1990. 821 с.

5. Жанр і стиль літературного імпресіонізму в Україні та США / укл. С.М. Пригодій. Київ : КДЛУ, 1996. 134 с.

6. Журба С. "Вертеп" Аркадія Любченка: музичний контекст. Філологічні студї: Науковий вісник Криворізького державного педагогічного університету : зб. наук. праць. Вип. 15. Кривий Ріг : НПП Астерікс, 2016. С. 151-163.

7. Кузнецов Ю. Імпресіонізм в українській прозі кінця XIX - поч. XX ст. Проблеми естетики і поетики. Київ : Зодіак - ЕКО, 1995. 304 с.

8. Наливайко Д. Теорія літератури й компаративістика. Київ : Вид. дім “Києво-Могилянська академія", 2006. 347 с.

9. Слово. Знак. Дискурс. Антологія світової літературно-критичної думки XX ст. / за ред. М. Зубрицької. Львів : Літопис, 1996. 636 с. 
10. Хвильовий М. Твори: у 2 т. Київ : Дніпро, 1990. Т.1 : Поезія, оповідання, новели, повісті. $650 \mathrm{c.}$

11. Фока М. Функціонування кольору в поетичних творах Павла Тичини. Украӥнська література в загальноосвітній школі. 2009. № 6. C. 2-7.

Information about the author: Zhurba S. S.,

Candidate of Philological Sciences, Docent, Associate Professor at the Department of Ukrainian and World Literature, Kryvyi Rih State Pedagogical University

54, Gagarin Avenue, Kryvyi Rih, Dnipropetrovsk region, 50000, Ukraine ORCID: https://orcid.org/0000-0002-6090-7742 